Elżbieta Kornacka-Skwara

Akademia im. Jana Długosza

w Częstochowie
Kiedy myślimy Rodzina..., red. M. Duda, K. Kutek-Sładek, Kraków 2016, s. 177-196 (Praca Socjalna w Teorii i Działaniu, 2).

\title{
Zagrożenia rodziny w percepcji osób o zróżnicowanych decyzjach emigracyjnych
}

\author{
The perception of threats to the family by people \\ with a different decisions of emigration
}

\begin{abstract}
The aim of this article is to pay attention to difficult situations of contemporary families. The author has conducted research of people who decided to emigrate and analyze family reasons of those decisions. In this article poses the question about the types of difficult situations experienced by the families of people with varying immigration decisions. Usually the literature provides the following types of difficult situations: the situation of deprivation, the overloading situations, the impediments situation, the situation of conflict and the situation of danger. The main research question is: Are there any differences in the experience and perception of the difficult situation for the family by people determined to emigrate and not interested in emigration? Specific research questions are: What situations are perceived
\end{abstract}

as threatening, impeding or do not constitute a threat to the modern family? Is there a relationship between subjective perception of threats to the family and the decision of emigration. Which of the situation, create a sense of danger? In the present study author deepens the analysis - looking for factors that may be called family stressors (workloads or threats) and checks their relationship with the decision to emigrate. There are differences in the experience and perception of the difficult situation for the family by people determined to emigrate and not interested in emigration. There are also relationship between the decision of emigration and sense of danger in own family.

Keywords: family, emigration, family relation, threats to families 
Ogólny kontekst zagrożeń dla funkcjonowania rodziny i rozwoju poszczególnych jej członków tworzą wielopłaszczyznowe zjawiska. W szerszym rozumieniu można się odwołać do płaszczyzny systemu społecznego i zjawisk o charakterze ekonomicznym, w nieco węższym znaczeniu należy wziąć pod uwagę przemiany w obszarze wartości, celów i modeli współczesnych rodzin i jej członków, natomiast na płaszczyźnie indywidualnej należy uwzględnić zarówno cechy i wartości osobiste, wartości relacyjne, jak i wpływy i presję pochodzącą z szerszych systemów ${ }^{1}$.

Współczesne rodziny polskie borykają się z różnorodnymi stresorami, co skutkuje między innymi zachwianiem bądź czasem wręcz niesprawnością procesów adaptacyjnych. Badania rodzin osób zdecydowanych na emigrację pokazują, że w percepcji zdeklarowanych emigrantów ich rodziny mają trudność $\mathrm{z}$ umiejętnością adaptacji i radzenia sobie w sytuacji doświadczania stresorów ${ }^{2}$.

W niniejszym artykule chcę odpowiedzieć na pytanie jakie jest poczucie bezpieczeństwa/zagrożenia rodzin w percepcji osób, które są zdecydowane na emigrację, oraz tych, które emigrację wykluczają.

\section{Podstawy teoretyczne badań}

Zgodnie z systemowym podejściem w psychologii człowiek żyje w kręgu systemów, a jednocześnie sam jako taki może być rozpatrywany w kategoriach systemu. System definiowany jest najczęściej jako zbiór elementów pozostających we wzajemnych relacjach ${ }^{3}$. Podstawowym systemem dla człowieka jest rodzina.

1 W literaturze przedmiotu wskazuje się na uwarunkowania zagrożeń, mające związek z procesami transformacji ogółu zjawisk i środowisk społecznych (przede wszystkim rodziny), których konsekwencją jest brak poczucia bezpieczeństwa i stabilności; uwzględnia się rozumienie wolności (bez odpowiedzialności za siebie i innych), marginalizujące lub wykluczające wartości moralne oraz bezkrytyczne przejmowanie modeli funkcjonowania człowieka, a zwłaszcza rodziny, promujących głównie wartości indywidualistyczne, a nie relacyjne. Por. B. Harwas-Napierała, Niektóre współczesne zagrożenia rozwoju w okresie dorosłości, „Psychologia Rozwojowa” t. 19 nr 2 (2014), s. 23-32; M. Straś-Romanowska, Szanse i zagrożenia rozwoju człowieka we współczesnym świecie, [w:] Rodzinne, edukacyjne i psychologiczne wyznaczniki rozwoju, red. J. M. Bogdanowicz, M. Lipowska, Kraków 2008, s. 15-24; T. Rostowska, Małżeństwo, rodzina, praca a jakość życia, Kraków 2008.

2 Należy wyraźnie zaznaczyć, iż badane rodziny były reprezentatywne w sensie socjodemograficznym - dla polskiej rzeczywistości rodzin, E. Kornacka-Skwara, Relacje rodzinne osób decydujących się na emigrację, [w:] Wyjechać czy pozostać? Wokół dylematów rynku pracy, red. M. Duda, B. Majerek, Kraków 2015.

3 L. von Bertalanffy, Ogólna teoria systemów. Podstawy, rozwój, zastosowania, tłum. E. Woydyłł-Woźniak, Warszawa 1984, s. 68. 
Bogdan de Barbaro wskazuje na cztery źródła stresu doświadczanego przez rodzinę ${ }^{4}$. Mogą one pochodzić spoza rodziny lub brać swój początek z wnętrza rodziny. Z drugiej strony, mogą oddziaływać bezpośrednio lub pośrednio na całą rodzinę. Pierwsze dwa źródła są pozarodzinne: stres działający na całą rodzinę, np. w przypadku zmiany miejsca zamieszkania, emigracji, załamania gospodarki; stres działający na jednego członka rodziny, a mogący rozprzestrzenić się na konkretny podsystem, jak i na cały system rodzinny ${ }^{5}$.

W przypadku emigracji z powodów zarobkowych mamy do czynienia ze wzmocnionym działaniem stresora - zarówno działającego bezpośrednio na całą rodzinę, jak i skoncentrowanego na jednym jej członku i oddziałującego na pozostałych. Szczególnego znaczenie nabiera fakt decyzji emigracyjnej młodego człowieka wkraczającego w swoje dorosłe życie. Jest on z jednej strony mocno zakorzeniony w rodzinie pochodzenia, $\mathrm{z}$ drugiej strony ma do zrealizowania własne zadania, zarówno o charakterze rozwojowym, jak i ról społecznych.

W psychologii człowieka dorosłego zwraca się uwagę na znaczenie ciągłości rozwoju dla kształtowania poczucia tożsamości warunkującego dojrzały, adekwatny sposób szeroko ujmowanego funkcjonowania. Koncepcja rozwoju psychospołecznego Erika Eriksona i zadań rozwojowych Roberta J. Havighursta - choć oparte na nieco innych założeniach teoretycznych - kładą nacisk na ciągłość rozwoju i znaczenie poprzednich faz/okresów dla formowania się i osiągania następnych ${ }^{6}$. Zadaniem człowieka w koncepcji Eriksona jest rozwiązywanie kryzysów, które stanowią naturalny czynnik rozwoju i przybliżają jednostkę do osiągnięcia coraz wyższego poziomu integracji. Efekt rozwiązania uprzednich kryzysów znajduje odzwierciedlenie w procesach rozwiązywania kryzysów bieżących. Dla człowieka dorosłego charakterystyczne będzie bazowanie na poczuciu intymności (wyważenie między lękiem a stabilnością kontroli „ja”) umożliwiającym realizację płodności i w kolejnym okresie - osiągnięcie akceptowalnego poziomu integralności . Pod pojęciem płod-

4 Wprowadzenie do systemowego rozumienia rodziny, red. B. de Barbaro, Kraków 1999, s. 53-55.

5 Np. sytuacja bezrobocia jednego członka rodziny wymusza zmianę w funkcjonowaniu rodziny, by mogła ona poradzić sobie z zaistniałą sytuacją. Jeśli rodzina nie będzie gotowa do takiej zmiany, mogą pojawić się w niej dysfunkcje. Za: Wprowadzenie do systemowego..., dz. cyt., s. 52.

${ }_{6}$ Erikson zakłada, że rozwój jest długotrwałym procesem kierunkowych zmian struktury i jej funkcji, zmierzającym ku określonym stanom końcowym lub celom, które $\mathrm{z}$ reguły są wartościowane pozytywnie.

7 E. H. Erikson, Dopetniony cykl życia, Poznań 2002, s. 72-75, 82-90. 
ności mieści się chęć posiadania potomstwa i opiekowania się nim z pełnym poczuciem odpowiedzialności rodzicielskiej.

Havighurst w odniesieniu do wczesnej dorosłości mówi o zadaniach rozwojowych ${ }^{8}$, związanych z założeniem i funkcjonowaniem w rodzinie, oraz podjęciem odpowiedzialności za utrzymanie i rozwój rodziny. Na te zadania składają się: wybór małżonka, uczenie się współżycia $z$ małżonkiem, powiększenie rodziny i wychowanie dzieci, prowadzenie domu, rozpoczęcie pracy zawodowej oraz znalezienie pokrewnej grupy towarzyskiej (społecznej).

W obydwu koncepcjach rozwój człowieka, a także jego podstawowa aktywność w okresie wczesnej dorosłości opiera się przede wszystkim na odwołaniu się do grupy społecznej, jaką jest rodzina. Pokonanie kryzysu bądź realizacja zadań rozwojowych umożliwia rozwój i kontynuację aktywności. W rozumieniu Eriksona kryzysy stanowią naturalne rozwojowe wyzwanie, z którym mierzy się człowiek. W rozumieniu Havighursta zadania rozwojowe są naturalnymi „wymogami”, którym może i powinien sprostać człowiek podczas swojego rozwoju. Istnieją sytuacje, które mogą rozwój zakłócić (utrudnić, a nawet uniemożliwić).

\section{Wyjazdy emigracyjne z Polski}

Emigracja zarobkowa z Polski jest faktem i przybrała postać exodusu. Statystyki GUS jednoznacznie wskazują na tendencję wzrostową (od 2010 roku) procesów emigracyjnych Polaków. „Szacuje się, że w końcu 2013 roku poza granicami Polski przebywało czasowo około 2196 tys. mieszkańców naszego kraju, tj. o 66 tys. (3,1\%) więcej niż w 2012 roku (około 2130 tys.). W Europie w 2013 roku przebywało około 1891 tys. osób (w 2012 roku - około 1816 tys.), przy czym zdecydowana większość - około 1789 tys. - emigrantów z Polski przebywała w krajach członkowskich UE. Liczba ta zwiększyła się o 69 tys. w stosunku do 2012 roku. Wśród krajów należących do UE nadal najwięcej osób przebywało w Wielkiej Brytanii (642 tys.), Niemczech (560 tys.), Irlandii (115 tys.) oraz w Holandii (103 tys.) i we Włoszech (96 tys.)"9. Powyższe statystyki należy interpretować jako niedoszacowane, bowiem nie uwzględniają osób, które wymeldowały się z pobytu stałego w Polsce, co wskazuje na stabilną decyzję emigracyjną.

8 Wprowadzenie pojęcia zadań rozwojowych jest zasługą Erika Eriksona i Roberta Havighursta, za: Z. Pietrasiński, Rozwój człowieka dorostego, Warszawa 1990, s. 82.

9 http://stat.gov.pl/obszary-tematyczne/ludnosc/migracje-ludnosci/informacja-orozmiarach-i-kierunkach-emigracji-z-polski-w-latach-20042013,2,7.html (3.03.2015). 
Tabela 1. Emigracje w 2013, Polska (wg miasto/wieś poprzedniego pobytu, płeć, stan cywilny)

\begin{tabular}{|c|c|c|c|c|}
\hline Płeć & Stan cywilny & Miasto & Wieś & Razem \\
\hline \multirow{5}{*}{ mężczyzna } & nieustalony & 811 & 347 & 1158 \\
\hline & kawalerowie & 5240 & 2061 & 7301 \\
\hline & żonaci & 3716 & 1672 & 5388 \\
\hline & wdowcy & 47 & 29 & 76 \\
\hline & rozwiedzeni & 735 & 216 & 951 \\
\hline \multirow{5}{*}{ kobieta } & nieustalony & 811 & 412 & 1223 \\
\hline & panny & 4982 & 2031 & 7013 \\
\hline & zamężne & 5289 & 2118 & 7407 \\
\hline & wdowy & 258 & 130 & 388 \\
\hline & rozwiedzione & 951 & 247 & 1198 \\
\hline \multicolumn{2}{|l|}{ razem } & 22840 & 9263 & 32103 \\
\hline
\end{tabular}

Źródło: Wybór własny na podstawie bazy Demografia GUS

Emigracja zarobkowa niesie w globalnym bilansie negatywne skutki dla kraju opuszczanego. Masowa emigracja jest też znakiem niewydolności struktur państwa, którego zadaniem jest wspieranie własnych obywateli i własnego kraju. Trudno zgodzić się z „pozytywnymi” wnioskami, pojawiającymi się w literaturze przedmiotu $\mathrm{w}$ analizie problemu emigracji:

Obok podstawowych korzyści z emigracji dla kraju wysyłającego, takich jak zmniejszenie bezrobocia i poprawa finansowania zewnętrznego dzięki transferom zarobków emigrantów, procesy migracji zagranicznych w powiązaniu z negatywnymi trendami demograficznymi w Polsce przyczyniają się do pogorszenia struktury demograficznej populacji, ograniczając perspektywy rozwoju gospodarczego i zaostrzając niektóre problemy związane ze zjawiskiem starzejącego się społeczeństwa ${ }^{10}$.

10 K. Maruszewska, Emigracja z Polski i jej skutki dla rodzin, „Prace Naukowe Uniwersytetu Ekonomicznego we Wrocławiu. Research Papers of Wrocław University of Economics" nr 292 (2013), s. 274-289. 
Zagrożenia związane z negatywnymi trendami demograficznymi i starzeniem się społeczeństwa mają niezbyt ścisły związek z procesami emigracyjnymi (rzeczywiście, osoby pozostające w Polsce zakładałyby rodziny i posiadałyby dzieci, jednak nie odwróciłyby „negatywnych trendów”). Wymieranie i starzenie się społeczeństw to problem bardziej skomplikowany niż tylko uwarunkowany wyjazdami emigracyjnymi.

Poniższa mapa obrazuje, jaki jest współczynnik dzietności w poszczególnych krajach świata. Szczególnie zagrożone, jeśli chodzi o zmniejszanie się liczby ludności, są kraje Europy środkowo-wschodniej.

W tym kontekście interpretacja mówiąca o pozytywnych skutkach emigracji wydaje się ponurym żartem.

W wymiarze osobowym masowa emigracja jest oznaką, że jednostka nie jest w stanie realizować podstawowych zadań rozwojowych ze względu na bariery, wobec których ma poczucie niemożności ich pokonania. Zgodnie z koncepcją systemową decyzja o emigracji staje się z jednej strony odpowiedzią na obciążające system rodzinny stresory, z drugiej strony jest źródłem kolejnych stresorów dla rodziny.

\section{Badania własne}

Celem badań było uzyskanie odpowiedzi na pytania związane z poczuciem zagrożenia rodzin polskich oraz rodzin własnych osób badanych. Hipoteza ba-

Rys. 1. Współczynnik dzietności w poszczególnych krajach świata w 2012 roku

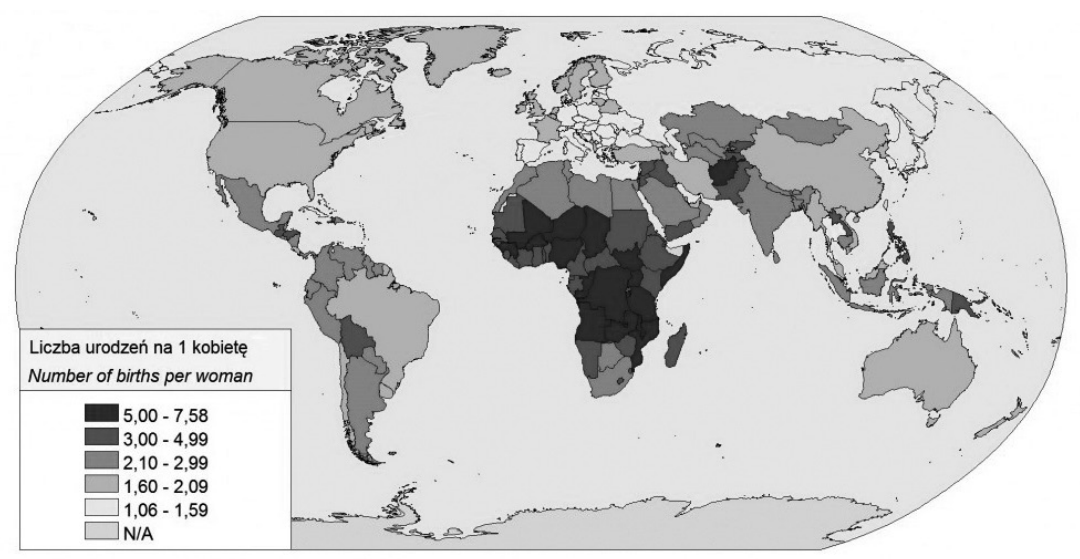

Źródło: World Development Indicators, database. 
dawcza pracy zakładała - zgodnie z koncepcją systemową - że decyzja o wyjeździe na emigrację nie jest działaniem związanym jedynie z osobą decydenta, ale ma związek z jego funkcjonowaniem w szerszym systemie, zwłaszcza w systemie rodzinnym.

Główne pytanie badawcze brzmiało: Czy istnieją różnice w doświadczaniu i postrzeganiu sytuacji trudnych dla rodziny przez osoby zdecydowane na emigrację i niezainteresowane emigracją?

Zostały postawione dwie hipotezy.

Hipoteza 1. zakładała, że osoby zdecydowane na emigrację oraz osoby decydujące się na to, by pozostać w kraju, różnią się postrzeganiem doświadczania sytuacji trudnych przez rodziny. Zatem szczegółowe pytania badawcze brzmiały:

Czy istnieje różnica między osobami emigrującymi i nieemigrującymi w zakresie poczucia zagrożenia doświadczanego przez ich rodziny? Jakie sytuacje trudne w percepcji osób zdecydowanych na emigrację budują poczucie zagrożenia rodzin?

Wskaźnikami w hipotezie pierwszej są ilość i rodzaje sytuacji.

Hipoteza 2. zakładała, że osoby zdecydowane na emigrację postrzegają/interpretują stresory doświadczane przez polskie rodziny inaczej niż osoby decydujące o pozostaniu w kraju. Zatem pytanie szczegółowe brzmiało:

Jak interpretowany jest dany rodzaj stresora w kontekście sytuacji trudnych dla rodziny przez obie grupy badanych?

Wskaźnikami w pytaniu drugim są kategorie stresorów, które wybrali badani: zagrażający, utrudniający, niestanowiący zagrożenia i niemający siły negatywnego oddziaływania na rodzinę.

Badaniami własnymi została objęta grupa 120 osób w okresie rozwojowym wczesnej dorosłości.

\subsection{Metoda badawcza}

Aby odpowiedzieć na pytanie o poczucie zagrożenia rodzin, autorka zastosowała kwestionariusz własnej konstrukcji oparty na koncepcji sytuacji Tadeusza Tomaszewskiego.

Tadeusz Tomaszewski ${ }^{11}$ (1979) w swojej koncepcji sytuacji charakteryzuje sytuacje trudne jako istnienie rozbieżności między potrzebami lub zadaniami a możliwością ich realizacji ze względu na działanie czynników zakłócających. Wymienia pięć głównych rodzajów sytuacji trudnej:

- sytuacja deprywacji, w której podstawowe potrzeby (fizjologiczne, psychologiczne, społeczne) człowieka nie są zaspokojone. Efektem sytuacji de-

11 Psychologia, red. T. Tomaszewski, Warszawa 1979, s. 17-30. 
prywacji jest np. obniżenie poziomu sprawności funkcjonowania organizmu (co powoduje obniżenie poziomu wykonywania czynności) lub dezorganizacja funkcjonalna;

- sytuacja przeciążenia związana jest z nadmierną trudnością zadania w porównaniu z możliwościami człowieka (fizycznymi, psychicznymi itd.) Efektem trwania w takich sytuacjach są często występujące zaburzenia nerwowe;

- sytuacja utrudnienia, która powstaje w przypadku pojawienia się przeszkody podczas wykonywania zadań lub braków przedmiotowych bądź informacyjnych, zakłócających czynności;

- sytuacja konfliktowa, charakteryzująca się oddziaływaniem na człowieka sprzecznych sił (fizycznych, społecznych, wartości, konfliktów, ról, zadań, kompetencji itp.);

- sytuacja zagrożenia, która związana jest z naruszeniem bądź prawdopodobieństwem naruszenia systemu wartości lub pojedynczej wartości z tego systemu; sytuacja zagrożenia może dotyczyć wszystkich płaszczyzn i dziedzin życia człowieka.

Ta sama sytuacja może być jednocześnie sytuacją deprywacji, przeciążenia, utrudnienia, konfliktu lub zagrożenia.

Kwestionariusz zawierał 10 rodzajów sytuacji trudnych, a zadaniem osób badanych było zakwalifikowanie ich do kategorii: zagrożenia, utrudnienia, braku zagrożenia lub braku ich negatywnego wpływu na funkcjonowanie rodziny.

Badania zostały przeprowadzone w okresie od stycznia do kwietnia 2015 roku.

\subsection{Opis grupy badanej}

Do badań dobrane zostały równoliczne grupy: 60 osób zdecydowanych na wyjazd emigracyjny oraz 60 osób, które nie wybierają się na emigrację. W każdej grupie było po 30 kobiet i 30 mężczyzn. Badani pochodzili z miast dużych, małych i średnich oraz ze wsi. Strukturę miejsca zamieszkania i płci przedstawia tabela 2.

Tabela 2. Struktura miejsca zamieszkania oraz płci

\begin{tabular}{|l|c|c|c|c|c|c|}
\hline \multirow{2}{*}{} & \multicolumn{3}{|c|}{ Kobiety } & \multicolumn{3}{c|}{ Mężczyźni } \\
\cline { 2 - 6 } & \multicolumn{2}{|c|}{ miejsce zamieszkania } & \multicolumn{2}{c|}{ miejsce zamieszkania } \\
\cline { 2 - 6 } & wieś & $\begin{array}{c}\text { małe/śred- } \\
\text { nie miasto }\end{array}$ & $\begin{array}{c}\text { duże } \\
\text { miasto }\end{array}$ & wieś & $\begin{array}{c}\text { małe/śred- } \\
\text { nie miasto }\end{array}$ & $\begin{array}{c}\text { duże } \\
\text { miasto }\end{array}$ \\
\hline $\begin{array}{l}\text { osoby } \\
\text { emigrujące }\end{array}$ & $11(37 \%)$ & $15(50 \%)$ & $4(13 \%)$ & $16(53 \%)$ & $14(47 \%)$ & $0(0 \%)$ \\
\hline $\begin{array}{l}\text { osoby } \\
\text { nieemigrujące }\end{array}$ & $14(47 \%)$ & $14(47 \%)$ & $2(7 \%)$ & $16(53 \%)$ & $12(40 \%)$ & $2(7 \%)$ \\
\hline
\end{tabular}


Wszyscy badani znajdowali się w okresie wczesnej dorosłości. Najwięcej badanych mieściło się w przedziale 20-23 lata. Strukturę wieku prezentuje wykres 1.

Kontrolowana była sytuacja rodzinna osób badanych. Wszystkie osoby (zarówno w grupie badawczej, jak i grupie porównawczej) były stanu cywilnego wolnego (kobiety niezamężne i mężczyźni nieżonaci). Badani pochodzili w zdecydowanej większości z rodzin pełnych (wykres 2.).

Kontrolowana była również liczba rodzeństwa osób badanych: $89 \%$ badanych posiadało rodzeństwo, $11 \%$ było jedynakami.

\subsection{Wyniki badań własnych}

Niniejsze wyniki badań pochodzą od 120 osób, z których 60 zadeklarowało, że podjęło decyzję o wyjeździe na emigrację, a 60 - że nie zamierzają wyjeżdżać na emigrację.

\section{Poczucie zagrożenia rodzin osób badanych}

Aby odpowiedzieć na pytanie, czy istnieje różnica między osobami emigrującymi i nieemigrującymi w zakresie poczucia zagrożenia swoich własnych rodzin, badani składali subiektywne deklaracje na temat poczucia zagrożenia.

Wykres 1. Struktura wieku

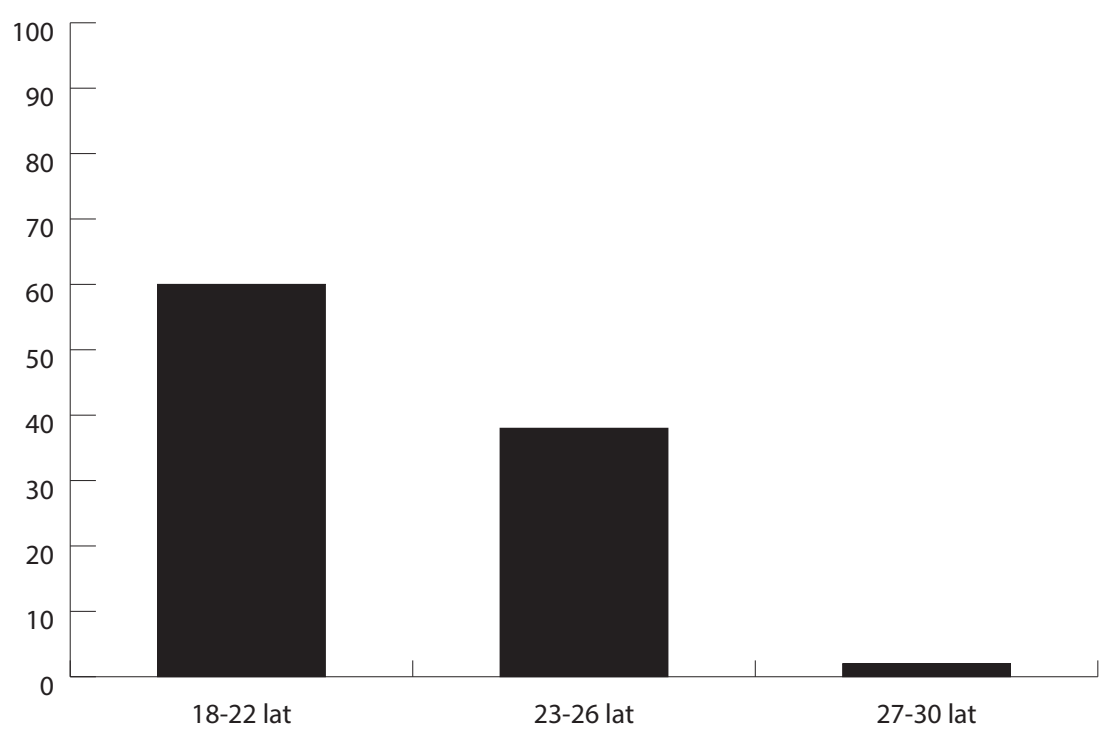

Źródło: badania własne. 
Wykres 2. Typ rodziny pochodzenia

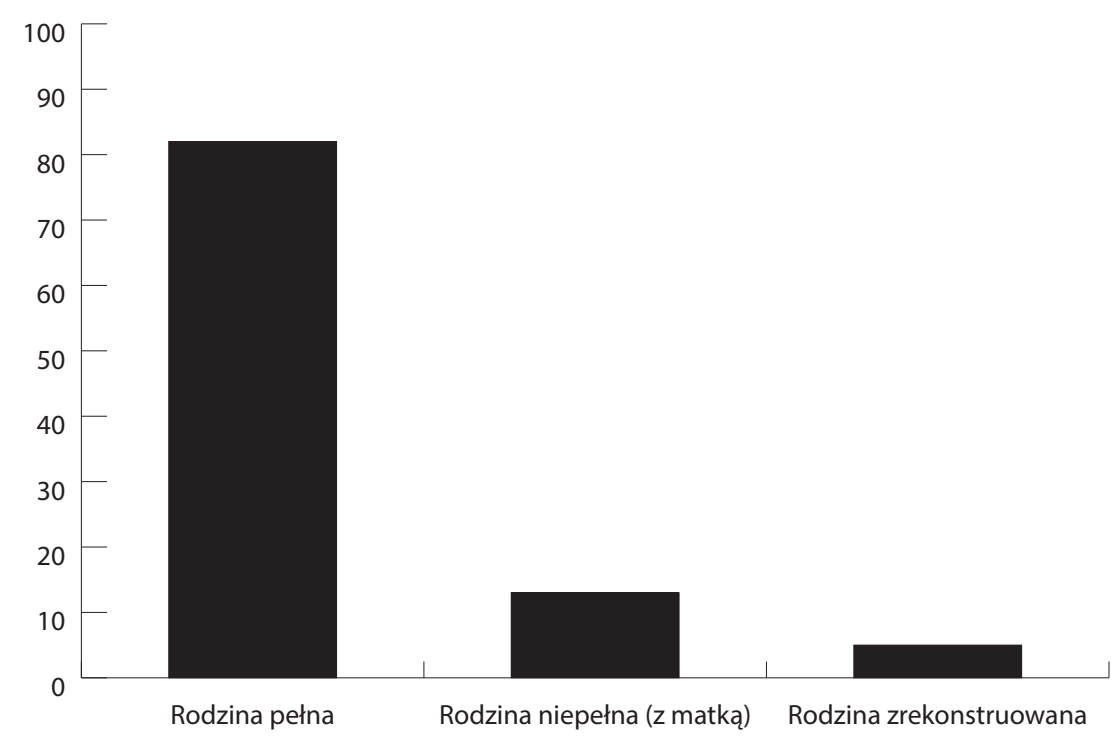

Źródło: badania własne.

Wśród osób emigrujących na pytanie: „Czy myślisz, że Twoja rodzina doświadcza poczucia zagrożenia?”, twierdząco odpowiedziało prawie $42 \%$, przecząco ponad $30 \%$, natomiast $25 \%$ badanych emigrujących odpowiedziało „nie wiem”. Porównanie z osobami, które nie biorą pod uwagę wyjazdu emigracyjnego, przedstawia tabela 3 .

Tabela 3. Poczucie zagrożenia dla rodziny w percepcji osób „emigrujących” i „nieemigrujących"

\begin{tabular}{|l|c|c|c|c|}
\hline \multirow{2}{*}{$\begin{array}{c}\text { Czzy myślisz, że Twoja rodzina } \\
\text { doświadcza poczucia zagrożenia? }\end{array}$} & \multicolumn{2}{|c|}{ Emigrujący } & \multicolumn{2}{c|}{ Nieemigrujący } \\
\cline { 2 - 5 } & $\mathrm{N}$ & $\%$ & $\mathrm{~N}$ & $\%$ \\
\hline tak & 25 & 41,6 & 18 & 30 \\
\hline nie & 20 & 33,3 & 24 & 40 \\
\hline nie wiem & 15 & 25 & 18 & 30 \\
\hline
\end{tabular}

Warto zauważyć, że poczucia zagrożenia doświadcza aż ponad 70\% wszystkich badanych. Różnice w przypadku tej kategorii występują na niekorzyść gru- 
py „emigrującej”. Różnica ma charakter tendencji, w której „emigrujący” częściej doświadczają poczucia zagrożenia swoich rodzin.

Drugie pytanie szczegółowe dotyczyło rodzajów doświadczanych przez rodziny osób emigrujących sytuacji trudnych, a dokładnie tego, które z tych sytuacji budują poczucie zagrożenia.

Poniższa tabela 4. przedstawia wyniki uzyskane przez osoby zdecydowane na emigrację. Pokazuje, jakie sytuacje były traktowane jako zagrożenie przez poniższe podgrupy badanych „emigrujących”:

- osoby emigrujące, które zadeklarowały, że ich rodzina doświadcza poczucia zagrożenia;

- osoby emigrujące, które stwierdzały, że ich rodzina nie doświadcza poczucia zagrożenia;

- osoby emigrujące, które na pytanie, czy mają poczucie, że ich rodzina jest zagrożona, odpowiedziały „nie wiem”.

Tabela 4. Sytuacje uznane przez „emigrujących” za zagrożenie dla rodziny, z uwzględnieniem subiektywnego stopnia poczucia zagrożenia

(Tak - moja rodzina doświadcza poczucia zagrożenia; Nie - moja rodzina nie doświadcza poczucia zagrożenia; Nie wiem, czy moja rodzina doświadcza poczucia zagrożenia)

\begin{tabular}{|c|c|c|c|c|c|c|}
\hline \multirow{3}{*}{$\begin{array}{l}\text { Rodzaj sytuacji, } \\
\text { która stanowi zagrożenie }\end{array}$} & \multicolumn{6}{|c|}{ Emigrujący (60) } \\
\hline & \multicolumn{2}{|c|}{$\begin{array}{l}\text { Rodzina } \\
\text { zagrożona } \\
(\mathrm{TAK}=25)\end{array}$} & \multicolumn{2}{|c|}{$\begin{array}{c}\text { Rodzina } \\
\text { niezagrożona } \\
(\mathrm{NIE}=20)\end{array}$} & \multicolumn{2}{|c|}{$\begin{array}{c}\text { Nie wiem, czy } \\
\text { moja rodzina } \\
\text { jest zagrożona } \\
(\mathrm{N}=15)\end{array}$} \\
\hline & $\mathrm{N}$ & $\%$ & $\mathrm{~N}$ & $\%$ & $\mathrm{~N}$ & $\%$ \\
\hline $\begin{array}{l}\text { brak wspólnych działań } \\
\text { (np. wykonywanie } \\
\text { wspólnie czynności, } \\
\text { spędzanie czasu wolnego) }\end{array}$ & 13 & 52 & 13 & 65 & 8 & 53 \\
\hline $\begin{array}{l}\text { nieumiejętność rozmawiania } \\
\text { ze sobą w rodzinie }\end{array}$ & 17 & 68 & 12 & 60 & 12 & 80 \\
\hline niedobory finansowe rodzin & 11 & 44 & 10 & 50 & 11 & 73 \\
\hline $\begin{array}{l}\text { tworzenie/rozbudzanie } \\
\text { potrzeb, propagowane } \\
\text { w mass mediach }\end{array}$ & 12 & 48 & 0 & 0 & 7 & 47 \\
\hline $\begin{array}{l}\text { zwiększający się udział } \\
\text { internetu w życiu rodzin }\end{array}$ & 11 & 44 & 3 & 20 & 3 & 20 \\
\hline $\begin{array}{l}\text { brak w rodzinie więzi } \\
\text { emocjonalnych łączących } \\
\text { jej członków }\end{array}$ & 22 & 88 & 16 & 80 & 15 & 100 \\
\hline
\end{tabular}




\begin{tabular}{|c|c|c|c|c|c|c|}
\hline \multirow{3}{*}{$\begin{array}{c}\text { Rodzaj sytuacji, } \\
\text { która stanowi zagrożenie }\end{array}$} & \multicolumn{6}{|c|}{ Emigrujący (60) } \\
\hline & \multicolumn{2}{|c|}{$\begin{array}{l}\text { Rodzina } \\
\text { zagrożona } \\
(\mathrm{TAK}=25)\end{array}$} & \multicolumn{2}{|c|}{$\begin{array}{l}\text { Rodzina } \\
\text { niezagrożona } \\
(\mathrm{NIE}=20)\end{array}$} & \multicolumn{2}{|c|}{$\begin{array}{l}\text { Nie wiem, czy } \\
\text { moja rodzina } \\
\text { jest zagrożona } \\
(\mathrm{N}=15)\end{array}$} \\
\hline & $\mathrm{N}$ & $\%$ & $\mathrm{~N}$ & $\%$ & $\mathrm{~N}$ & $\%$ \\
\hline $\begin{array}{l}\text { niejasne dla członków rodziny, } \\
\text { jakimi wartościami kieruje się } \\
\text { rodzina }\end{array}$ & 6 & 24 & 8 & 40 & 6 & 40 \\
\hline $\begin{array}{l}\text { brak wiedzy o sobie nawzajem } \\
\text { w rodzinie }\end{array}$ & 7 & 28 & 9 & 45 & 5 & 33 \\
\hline $\begin{array}{l}\text { ogólna sytuacja społeczno- } \\
\text {-ekonomiczna w Polsce }\end{array}$ & 6 & 24 & 7 & 35 & 9 & 60 \\
\hline $\begin{array}{l}\text { postawy członków rodzin } \\
\text { ukierunkowane na „mieć” }\end{array}$ & 9 & 36 & 5 & 25 & 9 & 60 \\
\hline inne & 8 & 32 & 8 & 40 & 4 & 27 \\
\hline
\end{tabular}

Osoby postrzegające zagrożenie dla swoich rodzin i te, które nie mają poczucia zagrożenia swoich rodzin, nie różniły się w zakresie większości sytuacji trudnych. Jednakże w 4 typach sytuacji wystąpiły zdecydowane różnice. W odniesieniu do sytuacji: „tworzenie/rozbudzanie potrzeb, propagowane w mass mediach” i „zwiększający się udział internetu w życiu rodzin”, częściej wskazywali na nie ci „emigrujący”, którzy mieli poczucie, że ich rodzina jest zagrożona. Na sytuacje: „niejasne dla członków rodziny, jakimi wartościami kieruje się rodzina” oraz „brak wiedzy o sobie nawzajem w rodzinie”, jako zagrażające częściej wskazywali badani „emigrujący”, którzy nie mieli poczucia zagrożenia swoich rodzin.

Interesujące wyniki uzyskane zostały przez trzecią podgrupę wśród „emigrujących”. Stanowiły ją osoby, które na pytanie o poczucie zagrożenia dla swoich rodzin odpowiedziały „nie wiem”. Na 10 merytorycznych rodzajów sytuacji trudnych w aż 6 rodzajach uzyskany wynik wynosił ponad 50\% wskazań na sytuacje określone jako zagrażające.

Wykres 3. ilustruje, które z sytuacji w największym stopniu budują poczucie zagrożenia rodzin w percepcji osób zdecydowanych na emigrację. Pokazuje on porównanie wyników osób zdecydowanych na emigrację, którzy zadeklarowali poczucie zagrożenia swoich rodzin, oraz tych „emigrujących”, którzy nie mają poczucia zagrożenia swoich rodzin bądź nie wiedzą, czy ich rodzina doświadcza poczucia zagrożenia. Uwzględnia on sytuacje, które w największym stopniu budują poczucie zagrożenia rodzin osób emigrujących (są to sytuacje, na które wskazało ponad 50\% osób). 
Wykres 3. Sytuacje stanowiące o poczuciu zagrożenie w percepcji osób „emigrujących”

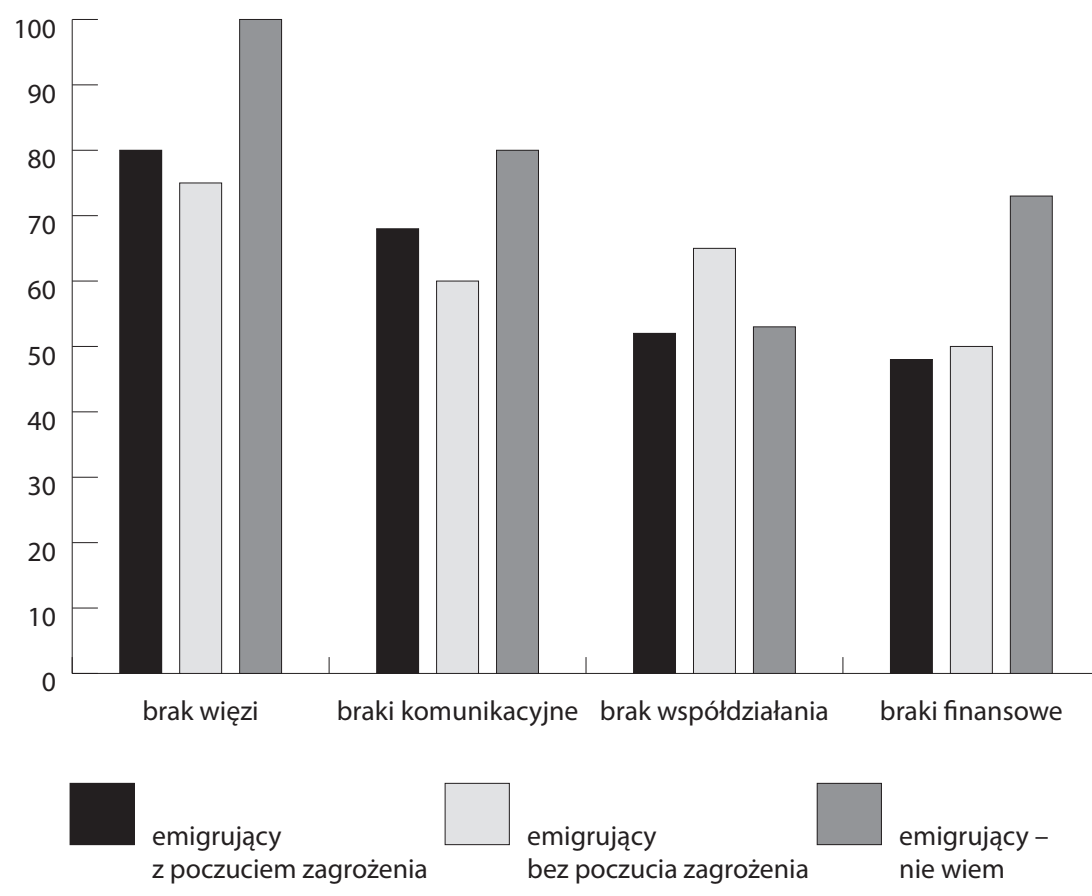

Źródło: badania własne.

Największym zagrożeniem w percepcji osób deklarujących poczucie zagrożenia ich rodzin są następujące sytuacje: „brak w rodzinie więzi emocjonalnych łączących jej członków”, „nieumiejętność rozmawiania ze sobą w rodzinie”, „brak wspólnych działań (np. wykonywanie wspólnie czynności, spędzanie czasu wolnego)” oraz „braki finansowe”. Emigrujący, którzy na pytanie, czy mają poczucie, że ich rodzina jest zagrożona, odpowiedzieli „nie wiem”, uzyskali w porównaniu z podgrupą emigrujących, którzy subiektywnie odczuwają, że ich rodziny są zagrożone, oraz w porównaniu z emigrującymi, którzy mają poczucie, że ich rodziny nie są zagrożone najwyższe wyniki w trzech wymienionych typach sytuacji (oprócz sytuacji „brak współdziałania”).

\section{Postrzeganie stresorów}

Hipoteza 2. zakładała, że osoby zdecydowane na emigrację inaczej postrzegają/interpretują znaczenie stresorów, które są doświadczane przez rodziny, niż osoby decydujące o pozostaniu w kraju. Pytanie szczegółowe brzmiało:

Jak postrzegają sytuacje trudne dla rodzin osoby emigrujące i nieemigrujące? Wskaźnikami były kategorie sytuacji trudnych, które wybierali badani (od 
najbardziej zagrażających do takich, które nie oddziałują negatywnie na rodzinę): 1 . sytuacje zagrażające rodzinie, 2 . sytuacje utrudniające, 3 . sytuacje niestanowiące zagrożenia dla rodziny i 4 . sytuacje niemające siły negatywnego oddziaływania na rodzinę.

Poniższe tabele (5-7) pokazują, jak sytuacje trudne dla rodzin postrzegane są przez osoby zdecydowane na emigrację („emigrujący”) oraz przez niewyjeżdżających na stałe z Polski („nieemigrujący”).

Aby odpowiedzieć na pytanie, jak te dwie grupy postrzegają dany rodzaj stresora w kontekście funkcjonowania rodziny, należało przyporządkować sytuacje do kategorii: 1. zagrażających, 2. utrudniających, 3. niebędących zagrożeniem oraz 4. niewpływających negatywnie na funkcjonowanie rodzin. Tabela 5. prezentuje wyniki uzyskane przez grupę „emigrujących” i „nieemigrujących”.

Obie grupy badane za sytuację najbardziej zagrażającą rodzinie uznały „brak więzi emocjonalnych w rodzinie łączących jej członków”. W 7 kategoriach nie było istotnych różnic między obydwoma grupami badanych.

Tabela 5. Sytuacje zagrażające w percepcji „emigrujących „i „nieemigrujących”

\begin{tabular}{|l|c|c|c|c|}
\hline \multirow{2}{*}{ Rodzaj sytuacji trudnej - sytuacja zagrożenia } & \multicolumn{2}{|c|}{ Emigrujący } & \multicolumn{2}{c|}{ Nieemigrujący } \\
\cline { 2 - 5 } & $\mathrm{N}$ & $\%$ & $\mathrm{~N}$ & $\%$ \\
\hline $\begin{array}{l}\text { brak wspólnych działań (np. wykonywanie } \\
\text { wspólnie czynności, spędzanie czasu wolnego) }\end{array}$ & 34 & 56,6 & 46 & 76,6 \\
\hline $\begin{array}{l}\text { nieumiejętność rozmawiania } \\
\text { ze sobą w rodzinie }\end{array}$ & 41 & 68,3 & 46 & 76,6 \\
\hline niedobory finansowe rodzin & 32 & 53,3 & 28 & 46,6 \\
\hline $\begin{array}{l}\text { tworzenie/rozbudzanie potrzeb, } \\
\text { propagowane w mass mediach }\end{array}$ & 19 & 31,6 & 10 & 16,6 \\
\hline $\begin{array}{l}\text { zwiększający się udział internetu } \\
\text { w życiu rodzin }\end{array}$ & 17 & 28,3 & 16 & 26,6 \\
\hline $\begin{array}{l}\text { brak więzi emocjonalnych w rodzinie } \\
\text { łączących jej członków }\end{array}$ & 53 & 88,3 & 52 & 86,6 \\
\hline $\begin{array}{l}\text { niejasne dla członków rodziny, } \\
\text { jakimi wartościami kieruje się rodzina }\end{array}$ & 20 & 33,3 & 32 & 53,3 \\
\hline brak wiedzy o sobie nawzajem w rodzinie & 21 & 35 & 20 & 33,3 \\
\hline $\begin{array}{l}\text { ogólna sytuacja społeczno-ekonomiczna } \\
\text { w Polsce }\end{array}$ & 22 & 36,6 & 8 & 13,3 \\
\hline $\begin{array}{l}\text { postawy członków rodzin } \\
\text { ukierunkowane na „mieć” }\end{array}$ & 23 & 38,3 & 23 & 38,3 \\
\hline \begin{tabular}{l} 
inne \\
\hline
\end{tabular} & 20 & 33,3 & 20 & 33,3 \\
\hline
\end{tabular}


Różnice między badanymi grupami pojawiły się w sytuacjach:

- ogólna sytuacja społeczno-ekonomiczna w Polsce - istotnie ta sytuacja częściej była postrzegana jako zagrożenie dla rodziny przez osoby „emigrujące";

- tworzenie/rozbudzanie potrzeb, propagowane w mass mediach - częściej była postrzegana jako zagrożenie dla rodziny przez osoby „emigrujące”;

- brak wspólnych działań (np. wykonywanie wspólnie czynności, spędzanie czasu wolnego) oraz niejasne dla członków rodziny, jakimi wartościami kieruje się rodzina - te sytuacje były postrzegane jako zagrożenie dla rodziny częściej przez osoby „nieemigrujące”;

Tabela 6. pokazuje, które sytuacje badani uznali za utrudniające funkcjonowanie rodziny.

Tabela 6. Sytuacje utrudniające w percepcji „emigrujących „i „nieemigrujących”

\begin{tabular}{|l|c|c|c|c|}
\hline \multirow{2}{*}{ Rodzaj sytuacji trudnej - sytuacja utrudnienia } & \multicolumn{2}{|c|}{ Emigrujący } & \multicolumn{2}{|c|}{ Nieemigrujący } \\
\cline { 2 - 5 } & $\mathrm{N}$ & $\%$ & $\mathrm{~N}$ & $\%$ \\
\hline $\begin{array}{l}\text { brak wspólnych działań (np. wykonywanie } \\
\text { wspólnie czynności, spędzanie czasu wolnego) }\end{array}$ & 20 & 33,3 & 14 & 23,3 \\
\hline $\begin{array}{l}\text { tworzenie/rozbudzanie potrzeb, } \\
\text { propagowane w mass mediach }\end{array}$ & 26 & 43,3 & 30 & 50,0 \\
\hline $\begin{array}{l}\text { nieumiejętność rozmawiania ze sobą } \\
\text { w rodzinie }\end{array}$ & 16 & 26,6 & 12 & 20,0 \\
\hline niedobory finansowe rodzin & 22 & 36,6 & 32 & 53,3 \\
\hline $\begin{array}{l}\text { zwiększający się udział internetu } \\
\text { w życiu rodzin }\end{array}$ & 22 & 36,6 & 18 & 30 \\
\hline $\begin{array}{l}\text { brak w rodzinie więzi emocjonalnych } \\
\text { łączących jej członków }\end{array}$ & 3 & 5,0 & 6 & 10,0 \\
\hline $\begin{array}{l}\text { niejasne dla członków rodziny, } \\
\text { jakimi wartościami kieruje się rodzina }\end{array}$ & 26 & 43,3 & 23 & 38,3 \\
\hline brak w rodzinie wiedzy o sobie nawzajem & 31 & 51,6 & 37 & 61,6 \\
\hline $\begin{array}{l}\text { ogólna sytuacja społeczno-ekonomiczna } \\
\text { w Polsce }\end{array}$ & 25 & 41,6 & 41 & 68,3 \\
\hline $\begin{array}{l}\text { postawy członków rodzin ukierunkowane } \\
\text { na „mieć }\end{array}$ & 24 & 40,0 & 27 & 45,0 \\
\hline inne & 15 & 25,0 & 9 & 15,0 \\
\hline
\end{tabular}

Największa różnica wystąpiła w postrzeganiu ogólnej sytuacji społeczno-ekonomicznej w Polsce - badani „nieemigrujący” istotnie częściej wskazywali, że jest to sytuacja utrudniająca funkcjonowanie rodziny. 
Tabela 7. pokazuje, które z sytuacji były przez badanych oceniane jako najmniej obciążające. Obie grupy badanych (odpowiednio 35\% i 40\%) w kategorii sytuacji najmniej obciążających rodziny najczęściej wskazywały zwiększający się udział internetu w życiu rodzin. Drugą sytuacją, która najczęściej była wybierana w kategorii niebędących utrudnieniem lub badani nie zauważyli, by wpływała negatywnie na funkcjonowanie rodzin, było tworzenie/rozbudzanie potrzeb, propagowane w mass mediach (odpowiednio ok. 26\% i 33\%).

Tabela 7. Sytuacje niebędące trudnymi lub niepostrzegane jako negatywnie wpływające na rodziny w percepcji „emigrujących” i „nieemigrujących”

\begin{tabular}{|l|c|c|c|c|}
\hline \multirow{2}{*}{\multicolumn{1}{|c|}{ Sytuacje niepostrzegane jako trudne }} & \multicolumn{2}{|c|}{ Emigrujący } & \multicolumn{2}{c|}{ Nieemigrujący } \\
\cline { 2 - 5 } & $\mathrm{N}$ & $\%$ & $\mathrm{~N}$ & $\%$ \\
\hline $\begin{array}{l}\text { brak wspólnych działań (np. wykonywanie } \\
\text { wspólnie czynności, spędzanie czasu wolnego) }\end{array}$ & 6 & 10,0 & 0 & 0 \\
\hline $\begin{array}{l}\text { tworzenie/rozbudzanie potrzeb, } \\
\text { propagowane w mass mediach }\end{array}$ & 15 & 25,9 & 20 & 33,3 \\
\hline niedobory finansowe rodzin & 6 & 10,0 & 0 & 0 \\
\hline $\begin{array}{l}\text { zwiększający się udział internetu } \\
\text { w życiu rodzin }\end{array}$ & 21 & 35 & 24 & 40,0 \\
\hline $\begin{array}{l}\text { brak w rodzinie więzi emocjonalnych } \\
\text { łączących jej członków }\end{array}$ & 4 & 6,6 & 2 & 3,3 \\
\hline $\begin{array}{l}\text { niejasne dla członków rodziny, } \\
\text { jakimi wartościami kieruje się rodzina }\end{array}$ & 14 & 23,3 & 5 & 8,3 \\
\hline brak w rodzinie wiedzy o sobie nawzajem & 8 & 13,3 & 3 & 5,0 \\
\hline $\begin{array}{l}\text { nieumiejętność rozmawiania ze sobą } \\
\text { w rodzinie }\end{array}$ & 3 & 5,0 & 2 & 3,3 \\
\hline $\begin{array}{l}\text { ogólna sytuacja społeczno-ekonomiczna } \\
\text { w Polsce }\end{array}$ & 13 & 21,6 & 11 & 18,3 \\
\hline $\begin{array}{l}\text { postawy członków rodzin ukierunkowane } \\
\text { na „mieć” }\end{array}$ & 14 & 23,3 & 10 & 16,6 \\
\hline $\begin{array}{l}\text { inne } \\
\text { inne }\end{array}$ & 25 & 41,6 & 31 & 51,6 \\
\hline
\end{tabular}

W przypadku najczęściej wybieranych sytuacji, takich jak: zwiększający się udział internetu w życiu rodzin oraz tworzenie/rozbudzanie potrzeb, propagowane w mass mediach, wśród emigrujących i nieemigrujących można wyróżnić co najmniej dwie podgrupy:

- pierwsza podgrupa to emigrujący, którzy zdecydowanie dostrzegają negatywny wpływ internetu w życiu rodzin - na tę sytuację jako utrudnienie 
i zagrożenie wskazało łącznie aż 65\% badanych. W przypadku nieemigrujących było to $60 \%$ badanych. Druga podgrupa to $35 \%$ emigrujących, którzy nie postrzegają takiego negatywnego wpływu.

- w odniesieniu do sytuacji negatywnego wpływu na życie rodzin poprzez tworzenie/rozbudzanie potrzeb, propagowanych w mass mediach, pierwsza podgrupa wśród emigrujących to ci, którzy zdecydowanie dostrzegają negatywny wpływ na życie rodzin tworzenia/rozbudzania potrzeb, propagowanych w mass mediach -jako utrudnienie i zagrożenie wskazało na tę sytuację łącznie aż prawie $75 \%$ badanych. W przypadku nieemigrujących było to $60 \%$ badanych. Druga podgrupa to $25 \%$ emigrujących, którzy nie postrzegają takiego negatywnego wpływu.

\subsection{Dyskusja wyników badań}

Przedstawione wyniki badań pokazują, że osoby zdecydowane na emigrację różnią się od osób, które nie chcą wyjechać z kraju, w zakresie postrzegania zagrożeń dla życia rodzin oraz subiektywnego poczucia zagrożenia własnej rodziny.

Hipoteza 1. zakładała, że osoby zdecydowane na emigrację oraz osoby decydujące się na to, by pozostać w kraju, różnią się w zakresie poczucia doświadczania sytuacji trudnych przez swoje rodziny. W odpowiedzi na pierwsze szczegółowe pytanie badawcze o istnienie różnicy między osobami emigrującymi i nieemigrującymi w doświadczaniu poczucia zagrożenia swoich rodzin wyniki pozwalają stwierdzić, że badani „emigrujący” nieco częściej niż „nieemigrujący” mieli poczucie, że ich osobista rodzina doświadcza poczucia zagrożenia (42\% „emigrujących” i 30\% „nieemigrujących”).

Odpowiedź na drugie szczegółowe pytanie badawcze pokazała, które sytuacje są wskazywane najczęściej w grupie emigrujących stwierdzających, że ich własna rodzina jest zagrożona. Brak więzi, umiejętności komunikowania się i współdziałania - to sytuacje najczęściej wskazywane przez emigrujących, którzy mieli poczucie, że ich osobista rodzina jest zagrożona. Ale - co niezwykle ciekawe - te same sytuacje wskazała grupa „emigrujących”, choć niedeklarujących zagrożenia swoich rodzin. Różnica wystąpiła w sytuacjach: „tworzenie/rozbudzanie potrzeb, propagowane w mass mediach” i „zwiększający się udział internetu w życiu rodzin”. Emigrujący z poczuciem zagrożenia częściej niż emigrujący bez poczucia zagrożenia wskazywali na te sytuacje, określając je mianem zagrażających rodzinom. Interesujące są wyniki trzeciej podgrupy emigrujących - tych, którzy nie wiedzieli, czy ich rodzina doświadcza poczucia zagrożenia. Okazuje się, że globalnie to właśnie oni wskazali najwięcej sytuacji, kwalifikując je do kategorii „zagrażających” (każda osoba badana z podgrupy 
„nie wiem” wskazała średnio po ok. 6 sytuacji zagrażających rodzinom; dla porównania: w podgrupie „tak”, czyli z poczuciem osobistego zagrożenia dla rodziny, było to średnio po 4,9 wskazań, w grupie „nie”, czyli z poczuciem braku zagrożenia dla rodziny, było to średnio po 4,5 wskazań).

Podsumowując, hipoteza 1. potwierdziła się częściowo. Założenie, że osoby zdecydowane na emigrację różnią się od nieemigrujących w zakresie poczucia zagrożenia swoich rodzin, potwierdziło się. Natomiast częściowo potwierdziło się założenie, że nieco inne sytuacje będą budowały subiektywne poczucie zagrożenia (lub jego brak). Większość osób emigrujących wskazywała na podobne sytuacje jako najbardziej zagrażające. Jak zatem interpretować wynik, który pokazuje, że „tworzenie/rozbudzanie potrzeb, propagowane w mass mediach” i „zwiększający się udział internetu w życiu rodzin” różnicuje badanych z poczuciem i bez poczucia zagrożenia? Wygląda na to, że nie tylko trudności w zakresie spójności, adaptacyjności i komunikowaniu się w rodzinie tworzą poczucie zagrożenia rodzin. Szerszy system jest obszarem postrzeganym jako zagrażający, ingerujący w wartości, sugerujący rodzinom dążenie do określonych celów (rozbudzanie/tworzenie potrzeb) poprzez oddziaływanie zarówno mniej kontrolowane przez rodziny (np. internet), jak i bardziej globalne (całościowe) za sprawą szeroko rozumianych mass mediów.

Hipoteza 2. zakładała, że obie grupy badane będą inaczej postrzegały (interpretowały) doświadczane przez polskie rodziny stresory. Należy stwierdzić, że hipoteza ta potwierdziła się częściowo, bowiem w aż 7 kategoriach nie było istotnych różnic między obydwoma grupami badanych. Interesujące wnioski można wyciągnąć, analizując 4 sytuacje różnicujące grupy „emigrującą” i „nieemigrującą”. Otóż „emigrujący” wskazywali na źródła stresu leżące poza rodziną ${ }^{12}$, czyli na ogólną sytuację społeczno-ekonomiczną w Polsce oraz tworzenie/rozbudzanie potrzeb, propagowane w mass mediach. Wynik ten jest spójny z wynikiem uzyskanym w odniesieniu do hipotezy pierwszej, gdzie szerszy system, nie tylko stresory wewnętrzne w systemie rodzinnym, był powodem odczuwania zagrożenia dla rodziny.

Osoby „nieemigrujące” wskazywały częściej na źródła stresu znajdujące się wewnątrz rodziny, czyli brak wspólnych działań (np. wspólne wykonywanie czynności, spędzanie czasu wolnego) oraz brak jasności dla członków rodziny co do tego, jakimi wartościami kieruje się rodzina. Natomiast o ogólnej sytuacji społeczno-ekonomicznej w Polsce badani „nieemigrujący” mówili, że jest to sytuacja utrudnienia, a nie zagrożenia. Odwołując się do teorii rozwoju psychospołecznego Eriksona, można powiedzieć, że prawdopodobnie badani „emigrujący” poprzez decyzję o wyjeździe szukają równowagi między lękiem

12 Por. Wprowadzenie do systemowego..., dz. cyt. 
a stabilnością kontroli „ja”. Mogą dzięki wyjazdowi zrealizować zadania rozwojowe, o których mówi Havighurst ${ }^{13}$, związane z założeniem i funkcjonowaniem w rodzinie oraz podjęciem odpowiedzialności za utrzymanie i rozwój rodziny. Wydaje się, że odzyskanie poczucia kontroli oraz podjęcie odpowiedzialności pozwoli zmniejszyć poziom poczucia zagrożenia rodzin. Badani pozostający w kraju dostrzegają zagrożenia dla rodzin, natomiast wygląda na to, że mają poczucie większej kontroli i sprawczości, jeśli chodzi o poradzenie sobie z zagrożeniami (bowiem są to obciążenia mające swoje źródła częściej wewnątrz rodziny).

\section{Zakończenie}

Rodziny w Polsce doświadczają wysokiego poczucia zagrożenia. Osoby zdecydowane na emigrację częściej odczuwają zagrożenia dla swoich rodzin (ponad $41 \%$ ) niż osoby, które są zdecydowane na to, by pozostać w kraju (w tej grupie $30 \%$ odczuwa zagrożenie). Można zaryzykować stwierdzenie, że osoby zdecydowane na emigrację mają ograniczone poczucie sprawczości na płaszczyźnie społecznej, gospodarczej i ekonomicznej. Ogólna sytuacja społeczno-ekonomiczna w Polsce oraz tworzenie/rozbudzanie potrzeb, propagowane w mass mediach, to sytuacje różnicujące grupy „emigrującą” i „nieemigrującą”. Mimo deklaracji, iż powodem decyzji emigracyjnej jest trudność w znalezieniu zatrudnienia (ewentualnie odpowiedniego zatrudnienia), z przedstawionych wyników badań wyłania się obraz młodych ludzi podejmujących decyzję o emigracji, którzy nie odnajdują się w ogólnej sytuacji społeczno-ekonomicznej w Polsce. W świetle koncepcji systemowej elementy systemów wpływając na siebie nie linearnie, a cyrkularnie tworzą spiralę wzajemnych zależności: zewnętrzna wobec rodziny sytuacja społeczno-ekonomiczna, wzorce życia i wartości pochodzące spoza rodziny przenikają do systemów rodzinnych. Nakładając się na obciążenia wewnątrzrodzinne, powodują jeszcze większe poczucie obciążenia stresorami, co do których badani „emigrujący” mają poczucie, iż nie sprawują nad nimi wystarczającej kontroli. Mechanizm ten jest cyrkularny i obejmuje wszystkich członków rodziny. W takiej sytuacji bardzo trudno jest uruchomić procesy adaptacyjne, które pomogą poczuć (odzyskać) kontrolę nad własnym funkcjonowaniem, szczególnie gdy zadania rozwojowe (bądź kryzysy) w zdecydowanym stopniu mają być zrealizowane (rozwiązane) w kontekście ról społecznych, poczucia stabilności i samosterowności. Wyda-

13 Wprowadzenie pojęcia zadań rozwojowych jest zasługą Erika Eriksona i Roberta Havighursta, za: Z. Pietrasiński, Rozwój..., dz. cyt., s. 82. 
je się, że dla emigrujących decyzja o wyjeździe jest elementem strategii odzyskiwania poczucia sprawczości i kontroli nad szerszym systemem w którym funkcjonują.

\section{Bibliografia}

Barbaro M., de, Struktura rodziny, [w:] Wprowadzenie do systemowego rozumienia rodziny, red. B. de Barbaro, Kraków 1999, s. 45-56.

Bertalanffy L., von, Ogólna teoria systemów. Podstawy, rozwój, zastosowania, Warszawa 1984, s. 68.

Erikson E. H., Dopetniony cykl życia, Poznań 2002, s. 72-75, 82-90.

Harwas-Napierała B., Niektóre współczesne zagrożenia rozwoju w okresie dorosłości, „Psychologia Rozwojowa" t. 19 nr 2 (2014), s. 23-32.

Kornacka-Skwara E., Relacje rodzinne osób decydujących się na emigrację, [w:] Wyjechać czy pozostać. Wokół dylematów rynku pracy, red. M. Duda, B. Majerek, Kraków 2015, s. 27-47.

Kostrzewa Z., Informacja o rozmiarach i kierunkach czasowej emigracji $z$ Polski w latach 2004-2013, opracowanie pod kierunkiem D. Szołtys, G. Marciniak, http://stat.gov.pl/ obszary-tematyczne/ludnosc/migracje-ludnosci/informacja-o-rozmiarach-i-kierunkachemigracji-z-polski-w-latach-20042013,2,7.html (3.03.2015).

Maruszewska K., Emigracja z Polski i jej skutki dla rodzin, „Prace Naukowe Uniwersytetu Ekonomicznego we Wrocławiu. Research Papers of Wrocław University of Economics” nr 292 (2013), s. 274-289.

Pietrasiński Z., Rozwój człowieka dorosłego, Warszawa 1990, s. 82.

Psychologia, red. T. Tomaszewski, Warszawa 1979, s. 17-30.

Rostowska T., Małżeństwo, rodzina, praca a jakość życia, Kraków 2008.

Straś-Romanowska M., Szanse i zagrożenia rozwoju człowieka we wspótczesnym świecie, [w:] Rodzinne, edukacyjne i psychologiczne wyznaczniki rozwoju, red. J. M. Bogdanowicz i M. Lipowska, Kraków 2008, s. 15-24. 